\title{
Use of a Virtual Platform to Evaluate Mental Performance, Mood State and Anxiety in a Third-Division Mexican Soccer Team
}

\author{
Mora Rosas Norma Elizabeth, PhD ${ }^{1}$, Natalia Lozano Virgen, $\mathrm{PhD}^{2}$ and Francisco Arroyo Paz, MD \\ ${ }^{1}$ Sport Psychology Coordinator, Sport Med Medical Centre, FIFA Medical Centre of Excellence, Mexico \\ ${ }^{2}$ Sport Psychology Assistant, Sport Med Medical Centre, FIFA Medical Centre of Excellence, Mexico \\ ${ }^{3}$ Medical Director, Sport Med Medical Centre, FIFA Medical Centre of Excellence, Mexico
}

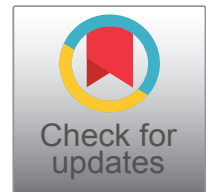

*Corresponding author: Francisco Arroyo, MD, Medical Director, Sport Med Medical Centre, FIFA Medical Centre of Excellence, Mexico, Tel: (0133)-36-56-69-99; (0133)-36-56-72-33

\begin{abstract}
The psychological evaluation for soccer players should be conducted during different times of the regular season, as it can provide relevant data that are useful for the coach and his multidisciplinary assistant's team. Generally speaking, this evaluation is carried out by a sports psychologist and takes time to apply to the entire team, which makes the scoring process and data interpretation take longer, especially if this is carried out by a single psychologist in the traditional way.

Because of this we have designed a Psychological Test on a Virtual Platform, in which soccer players can have access via cellular phones, tablets or computers simultaneous, achieving immediate results and evaluating more players.

This Psychological Test was conducted on a third-division Mexican soccer team, for 2 consecutive days, having immediately results and graphics, those results were shared with coach and assistants during the following week.
\end{abstract}

\section{Keywords}

Psychological performance evaluation, Emotional status, Anxiety, Soccer, Mental training, Sports performance, Digital platform for psychological assessment

\section{Introduction}

Psychological performance, emotional status and anxiety are psychological variables presented in soccer players, it is well known by the coaches that they can determine the outcome of a game during the key moments of the season or even during training. However, they don't have the specific information of this emotional status, that can help them to plan the appropriate strategies or a proper intervention to improve psychological performance, balance emotional status or decrease anxiety in soccer players.

A coach has a multidisciplinary team with a physical therapist, sports medicine doctor, kinesiology, and physical trainer, but not so often they have a psychologist on the team or in any category, in Mexico these professionals are very few. Because of this, all psychological aspects in any category of any soccer team have been neglected, as well as the psychological evaluations for players.

Coaches generally have incredibly good observation capacity and good communication with the players, so they can infer emotional problems or psychological situations, but only by intuition.

Traditionally, psychological evaluation is performed by answering paper questionnaires or in some cases digital files, which implies more manual work for the psychologist, delaying the timely delivery of the results to the coach or the technical director.

By doing an online search for webpages worldwide, we found no platform where the players can take simultaneously a psychological test and have results in seconds or a website where coaches can have access to make a psychological evaluation test for their players.

For this reason, we requested a system engineer to develop a virtual platform, to digitalize the test and cap-

Citation: Elizabeth MRN, Virgen NL, Paz FA (2020) Use of a Virtual Platform to Evaluate Mental Performance, Mood State and Anxiety in a Third-Division Mexican Soccer Team. Int J Sports Exerc Med 6:170. doi.org/10.23937/2469-5718/1510170

Accepted: July 14, 2020; Published: July 16, 2020

Copyright: (c) 2020 Elizabeth MRN, et al. This is an open-access article distributed under the terms of the Creative Commons Attribution License, which permits unrestricted use, distribution, and reproduction in any medium, provided the original author and source are credited. 
ture the elements and implement the results on charts.

The online digital platform we developed provides users with some more clinical test that can be applied into the sports area, one example of this is the Psychological Performance Test of Loehr.

\section{Psychological Evaluation on Soccer Players}

Soccer is actually one of the most evolved and popular sport around the globe [1] and because of this, soccer has been looking to have a multidisciplinary backup to help players to achieve full performance and it is that in this situation that Sport Psychology has a key role.

There is a lot of research to probe that the technical and tactical aspects of the game are also related top psychological aspects and an example of this is the research Garcia, González, Ponce, Tomé \& Vales [2], the study refers to the mental load that have the players during training; meanwhile Paso, Sáenz \& Fadua study [3], concludes that the player training sessions must also be planned with psychological aspects, so they must integrate the emotional, affective and social aspects in these training sessions along with the tactic, technical and physical condition aspects. Almagro, Sáenz \& Moreno [4] mention that the training sessions should be focus on the homework climate where the effort and the fun of the players is primordial, giving all this an increased intrinsic motivation and also an adherence to practice soccer.

Pazo, Sáenz \& Fradua [3] comment that "a psychological level, the player must have tests such as: Interviews, questionnaires, etc., done by specialists, to have references on these aspects. Also, to pay attention to the players and work with them individually, and with those who require it if is necessary [5]. On the other hand, Olmedilla [6], mention that using a psychological skills evaluation tool can allow us to establish a working hypothesis about the most appropriate psychological intervention to promote sports performance".

De la Vega [7] states that in the Sport Psychology, the sport psychologist duty has to be adapted to the context, this means, to be adapted to the soccer field, this author mentions that due to the context where the soccer is played, sometimes it is difficult to obtain the results that we are looking for, because most of the time, evaluations and immediate results are difficult to get especially to know how the player is at that specific moment, this can hinder the duty of the sports psychologist and the possible intervention that can be done later. Therefore, as mentioned above, the sports psychologist must adapt to the sport context and available resources. So, if we can count now with the use of technology, the opportunity to do psychological tests and obtain results in real time, this could help them to do a psychological intervention, as well as provide important information to the coach's technical assistants about their player.

On this subject, García [8] mentions that: "there is no doubt that actual technology means a big help in systematizing and obtaining objective data for then analysis of sport performance".

Taking the test online offers a lot of advantages, one of these is how fast we can obtain the results once the test of evaluation is completed [9]. Díaz [10] also mentions that another advantage is that the resources and the personnel to do it are minimal.

In general, we can talk about: "available programs and instructional materials, so it may be relatively easy for a new researcher in this field to implement simple studies to run through the web" [11].

\section{Objectives}

1. Through a Digital Psychological Testing Platform, designed specifically for Sport Med Centro Medico, México (FMCE), the goal was to evaluate a Third-Division Mexican Soccer team, and present the results of these evaluations to the coach and his assistants, so in the future they will be able to design interventions and to detect particular cases that require support and also to offer data that can be useful for planning sports training.

2. To test the Digital Platform specially design for FMCEand evaluate its functionality and its massive future application in the context of National and International soccer.

\section{Methods}

The coach selected the group of athletes to be evaluated, who were assigned a specific time to attend the Sport Med Centro Medico, México (FMCE) facilities.

Two psychologists participated in the evaluation process, who explained to the players how to access the platform and to answer the psychological tests.

\section{Participants}

The study participants were 12 Third-division soccer players from the Cafesa group. The age range of the players was between 15 and 20-years-old, who train 2 hours in the morning, because they are high school students in the afternoon.

The team consists of a head coach, two technical assistants, a sports medicine doctor, and a physical trainer.

\section{Instrument}

Digital Platform named Matrix AdminPsycho-test, design to evaluate athletes using three psychological tests, all of them used in their Spanish version.

a) Test POMS (Profile of Mood States) from McNair, Lorr \& Doppleman [12]. 
b) Trait -State Anxiety Inventory (IDARE) de Díaz-Guerrero \& Spielberger [13].

c) LOHER Psychological Performance Test [14].

All participants answered the tests on the "Matrix Admin" platform and at the end of the process the results were obtained immediately in graphical form.

\section{Process}

The evaluation was done during the following two days and we have 12 football soccer players in total scheduled at different times and at a simultaneous hour in groups of 4 soccer players.

Before the players answered the online tests, psychologists conducted a brief interview and an explanation of the study's intent and created a username and a password for each participant to access the platform and answer the test.

Previous the psychological evaluation there was an explanation for the players about the objective of the test and we also gave them a document where they put basic general information. Once they complete the information, we show them the link, so through their cellular phones they enter the website to answer all the assigned items.

To do the test, all the information about the tests was also given to the players so they know how to answer and what was the order to follow (POMS, IDARE and LOEHR), and the last indication was to please answer the questions in a honest way.

At the end of the test, participants were informed that an individual report would be submitted, as well as the head coach.

\section{Results}

The results are shown in graphs in the Loehr and POMS tests, while in the IDARE test they are shown in a table. This process should be improved to facilitate data processing between tests. The table results of the Profile of Mood States (POMS) individually Figure 1.

The STAI test measures the two aspects of anxiety, trait, and state. The results are show by positive and negative responses by the two aspects. Figure 2 shows the individual results of this anxiety measurement.

The Loehr Psychological Performance Test measures different psychological variables that are presented in graph form and evaluated in a way that suggests relevant attention at its appropriate level. Figure 3 shows how it appears on the platform.

\section{Platform Advantages and Limitations}

As has been discussed throughout this article, the advantages of the internet evaluations are many, low cost, maximum utilization in personnel, fast results, etc. However, there are also limitations on this topic specifically in the platform that was used to do the evaluations, another one is the difficulty of the results by group, so we must translate the results to anExcel page.

On the other hand, one of the advantages the MATRIX ADMIN PSYCHOTEST platform is that we can get the results from the different tests at the same time that the player finishes answering the questions, obtain-

\section{PROFILE OF MOOD STATE}

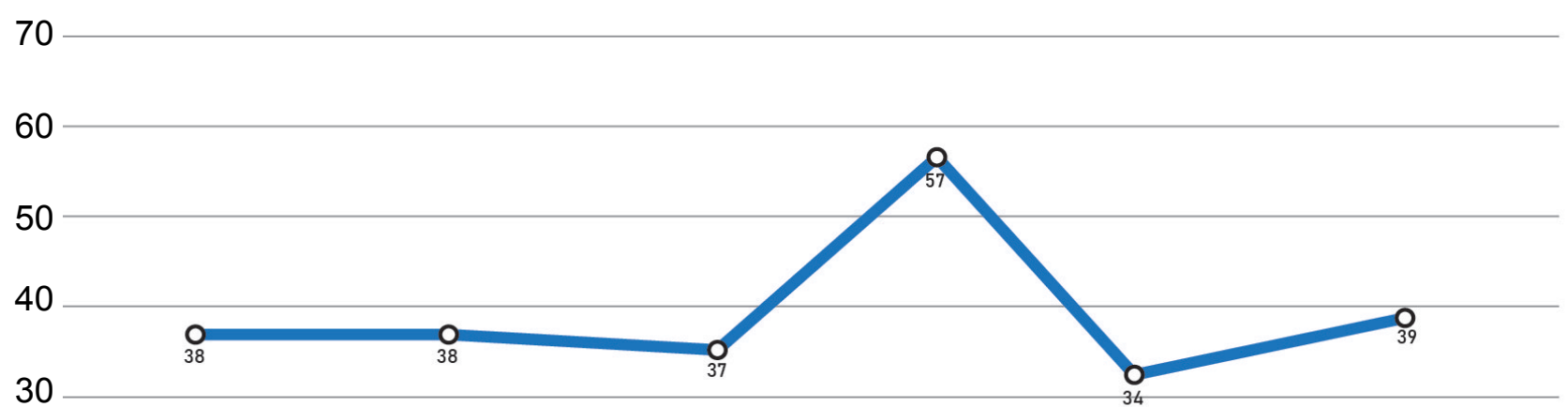

20

10

0

$\begin{array}{llll}\text { TENSION DEPRESSION ANGER VIGOR FATIGUE CONFUSION } & \end{array}$

Figure 1: Profile of Mood States (POMS). 


\section{STAI}

80

70

60

50

40

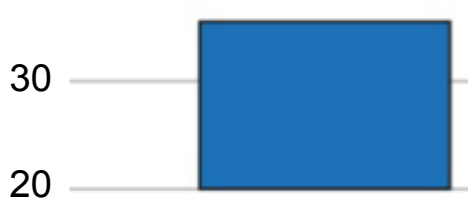

STATE ANXIETY

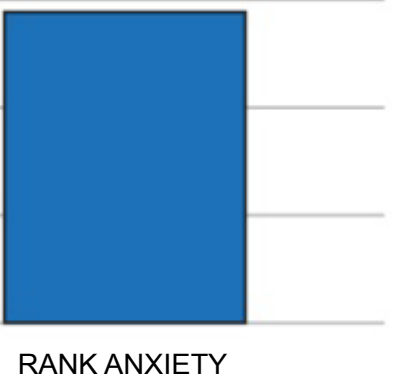

VRYLOW ANXIETY

20-31

LOW ANXIETY

$32-43$

AVERAGE ANXIETY

44-55

HIGH ANXIETY

56-67

VERY HIGH ANXIETY

Figure 2: STAI.

\section{PSYCHOLOGICAL PERFORMANCE PROFILE}

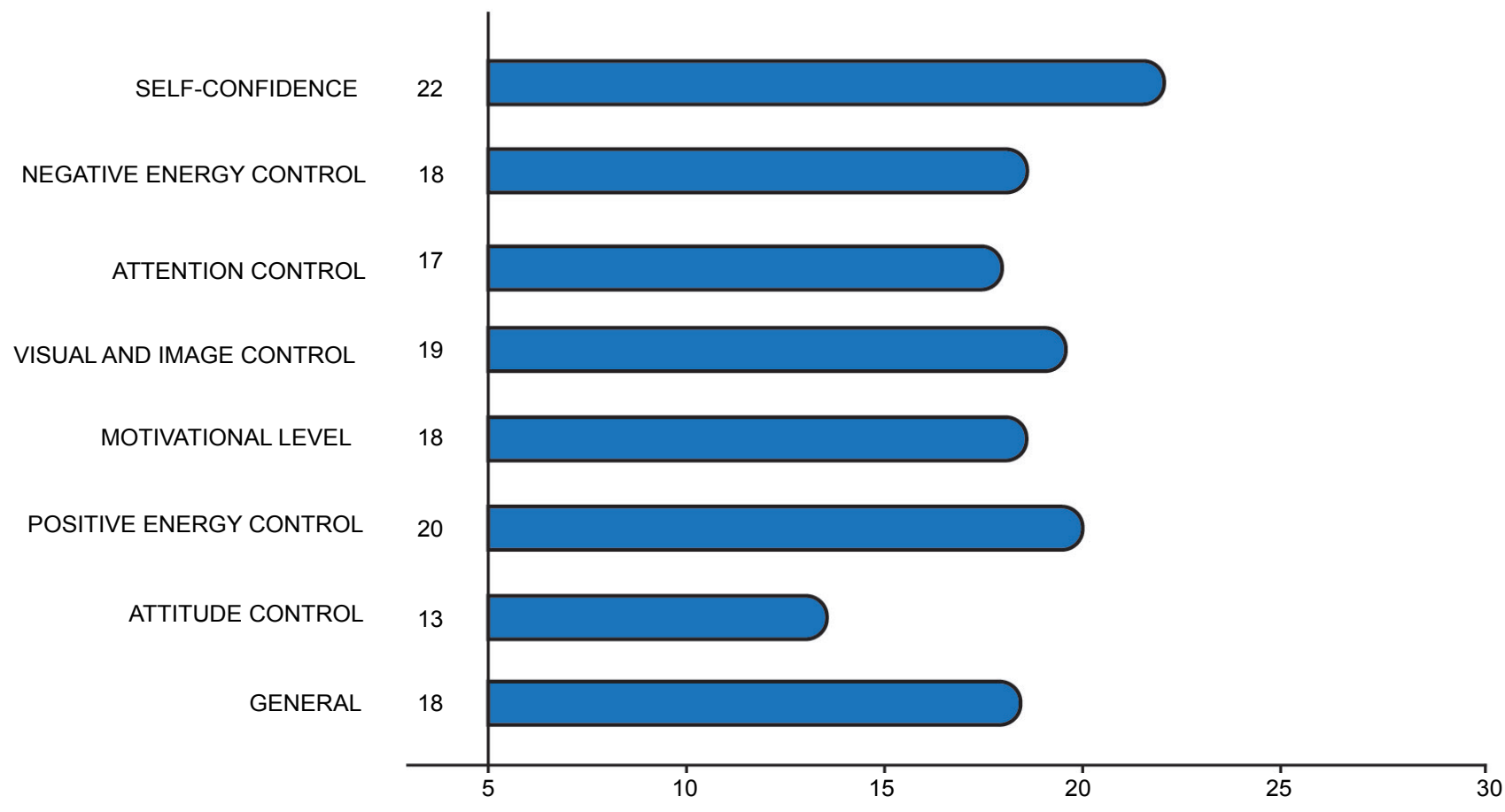

Figure 3: Psychological Performance profile.

ing not only the percentages, but also their respective graphics, so this makes the work easier for the Sport Psychologist when the report is being made.

Another advantage of the platform is that it allows a simultaneous evaluation of several players, in this research we made 4 payers simultaneous evaluation and they were answering the questions via cell phone or ac- cess through a computer, a laptop, an iPad it doesn't matter if is android or IOS.

\section{Conclusions}

The simultaneous Psychological Evaluation for football soccer players was efficient because in just two days we obtained individual and group graphics of each of 
the 3 tests and because of this type of evaluation there was not waste of paper (only one paper sheet was use for each participant).

Implementing new systems and digital platforms to be able to do simultaneous evaluation in the Soccer area is a challenge in this era and that can be offered to national and international teams. Also, the data obtained from the psychological scope can be the complement to the multidisciplinary team to improve the comprehensive management of the player in any category.

There is no doubt that the work between the Psychologist and the Systems Engineer is ideal to offer and satisfy the needs of the Sport Psychological Area and to be a complement with the other Sport Science professionals to offer real-time and real data that is so necessary in this era.

\section{Acknowledgements}

We would like to express our gratitude to Rani Jarkas, President of the Cedrus Group and Oliver B. Hasler, CEO of Sport Med Innovation Hospital (Shanghai) for all their support and the facilities they provided us during the cooperation study between the following institutions: Sport Med Centro Medico, México and Sport Med Innovation Hospital (Shanghai), China.

We also want to thank the team's football soccer players for their kindness and willingness throughout the study.

\section{References}

1. García S, Rodríguez A, Garzón A (2011) Conceptualización De InteligenciaTácticaen Fútbol: Consideraciones Para El Desarrollo De Un Instrumento De Evaluaciónen Campo Desde Las Funciones Ejecutivas. Cuadernos de Psicología Del Deporte 11: 69-78.

2. García-Calvo T, González-Ponce I, Carlos Ponce J, Tomé-Lourido D, Vales-Vázquez Á (2019) Incidencia del sistema de puntuación de las tareassobre la carga mental del entrenamientoenfútbol. Revista de Psicología Del Deporte 28: 79-86.

3. Pazo Haro C, Sáenz-López Buñuel P, Fradua Uriondo L (2012) Influencia del contextodeportivoen la formación de los futbolistas de la selecciónespañola de fútbol. Revista De Psicología Del Deporte 21: 291-299.

4. Almagro B, Sáenz-López P, Moreno JA (2010) Prediction of sport adherence through the influence of autonomy-supportive coaching among Spanish adolescent athletes. J Sports Sci Med 9: 8-14.

5. Martindale R, Collins D, Wang J, McNeill M, Lee K, et al. (2010) Development of the Talent Development Environment Questionnaire for Sport. J Sports Sci 28: 1209-1221.

6. Olmedilla A, Ortega E, Andreu MD, Ortín FJ (2010) Programa De IntervenciónPsicológicaenFutbolistas: Evaluación De HabilidadesPsicológicas Mediante El Cprd. Revista de Psicología Del Deporte 19: 249-262.

7. De la Vega R (2004) Pilaresbásicos de la intervenciónpsicológicarealizadaen el fútbolprofesional. Cuadernos de Psicología del Deporte 4: 159-180.

8. Garcia O (2011) El análisis de la realidad del fútboldesde una perspectivacientífica. Revista De Psicología Del Deporte 20: 814-815.

9. González-Ruiz SL, Domínguez-Alfonso R, Chica-Merino E, Pastrana-Brincones JL, Hernández-Mendo A (2018) Una plataforma virtual para la evaluación e investigación on-line: MenPas. Cuadernos de Psicología Del Deporte 18: 26-48.

10. Díaz de RadaV (2012) Ventajas e inconvenientes de la encuesta por Internet. Papers: Revista de Sociología 97: 193-223.

11. Birnbaum MH (2004) Human research and data collection via the Internet. Annu Rev Psychol 55: 803-832.

12. McNair D, Lorr M, Doppleman L (1971) POMS Manual for the Profile of Mood States. San Diego, CA: Educational and Industrial Testing Service.

13. Díaz-Guerrero R, Spielberger CD (1975) IDARE: Inventario de ansiedad: rasgo-estado. México: El Manual Moderno.

14. Loehr J (1986) Mental toughness training for sports. Achieving athletic excellence. Lexington, MA: Stephen Greene Press. 